\title{
The Integrated Pest Management, Biotechnology and the Challenges That Biotechnology Is Likely to Face
}

\author{
Rostern Tembo \\ Western Kentucky University, Bowling Green, 42101 KY, USA
}

\begin{abstract}
The paper discusses the advantages of biotechnology, the challenges it will face, the global food demands as world population grows and the need for the balance between biotechnology and traditional technology to enhance food production. Genetically modified crops have a number of advantages than conventional crops, so have caused a good number of farmers across the world to embrace biotechnology. The projected rise in the world population by 2050 to be at 9.7 billion and by 2100 at approximately 11 billion has led to adoption of biotechnology in an attempt to meet the global food requirements. The foreseeable challenges will be the sustainability of genetically modified crops against insects' resistance and the safety of these genetically modified crops. We are at a stage in human development, where we need a balanced approach to solving this world challenge of hunger and malnourishment, a safe sustainable approach using the best of the conventional crop technology and the best of biotechnology to achieve sustainable intensification of crop productivity on the 1.5 billion ha of cropland globally.
\end{abstract}

Key words: Transgenic crops/foods, genetically modified plants, semiochemicals, pull and push strategy, Cry-proteins, genetically modified crops.

\section{Introduction}

Biotechnology has been in use, since ancient brewers began using yeast cultures to make beer. The break through that laid the ground work for the coming of modern biotechnology was a result of the discovery of the structure of DNA in the early 1950s [1]. DNA is a very long and coiled molecule found in the nucleus or command center of a cell. It provides the full blueprint for the construction and operation of life form, for a microbe, a bird, a human being or an elephant. Biotechnology has revolutionized the diagnosis of diseases caused by genetic factors. New tests can detect changes in the DNA sequence of genes associated with disease risk, and can predict the likelihood that a patient will develop a disease [1]. A genetically modified organism (GMO) is a plant or an animal that has been genetically modified through the addition of a small amount of genetic material from other organisms through molecular techniques. The

Corresponding author: Rostern Tembo, Ph.D., research field: integrated pest management/chemoreception.
GMOs on the market today, at least in the USA, have been given genetic traits to provide protection from pests, tolerance to pesticides, and resistance to drought or improve its quality. Examples of genetically modified (GM) field crops include potatoes, sweet corn, corn, soybean, etc. The US Food and Drug Administration (FDA) regulate GM foods and consider GM foods to be nutritionally equivalent to traditional corn.

There are four GM crops that grown around the world. These are soy bean, corn, cotton and canola, and account for almost 99\% of the world's GM crops [2]. Almost all GM crops are engineered with one or both of two traits: herbicide tolerance (accounts for 85\% of GM crops) and insect resistance. Ten countries account for $98 \%$ of the global hectares of GM crops. The top three countries that cultivate GM crops are the USA, Argentina and Brazil accounting for over three quarters of global GM hectares (Fig. 1). The main thrust of this review paper is to discuss various methods of pest management and their challenges. 


\section{Advantages of Biotechnology}

The capacity to manipulate genes among unrelated species is a major technological breakthrough in modern production of food throughout the world. Transgenic insect-resistant maize Zea mays L. (Poaceae), and cotton Gossypium species (Malvaceae) and expressing Bacillus thuringiensis Berliner (Bt) proteins have been adopted rapidly worldwide, since they were first commercialized in 1996. The USA has been the leading country in adopting GM crops. In 2009, the USA planted 22 million ha of GM maize, accounting for $63 \%$ of its total maize area, and 2.4 million ha of GM cotton, accounting for $65 \%$ of its total cotton area [3]. Definitely, many benefits that are there in using GM crops can be exploited, such as the following:

(1) The control of Ostrinia nubilalis. Cry1Ab, the protein toxin in GM corn, has been transformed into several generic events by several seed companies. Hybrids with the YieldGard ${ }^{\circledR}$ technology provide 98\% control of first and second generation of European corn borers. This solves the problem of monitoring the generations of European corn borers in a planting season.

(2) The elimination of yield loss. The GM corn protects the corn from European corn borer injury and yield loss associated with stalk tunneling.

(3) The elimination of the use of insecticides which

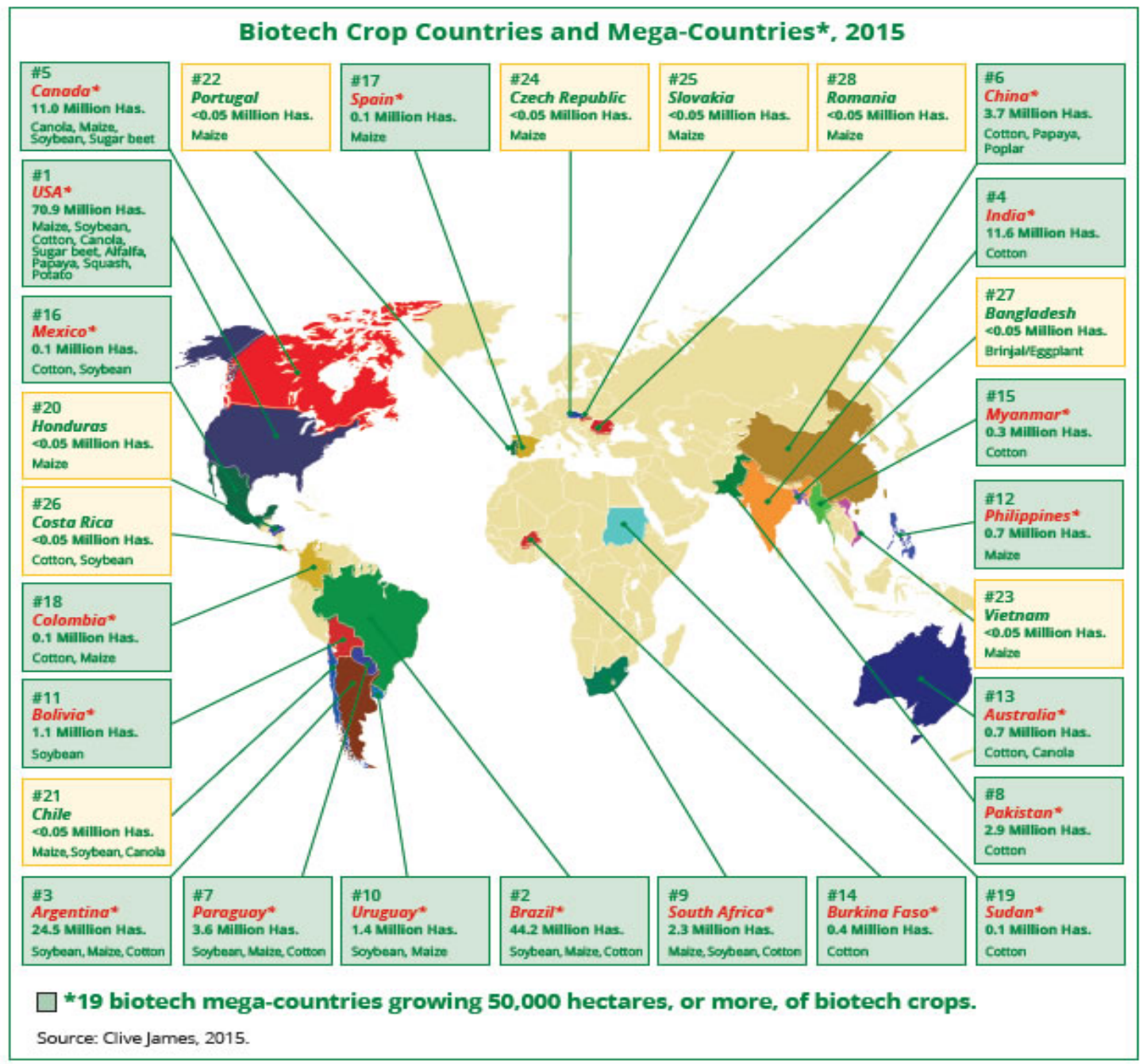

Fig. 1 Global map of biotech crop countries and mega-countries in 2015 [4]. 


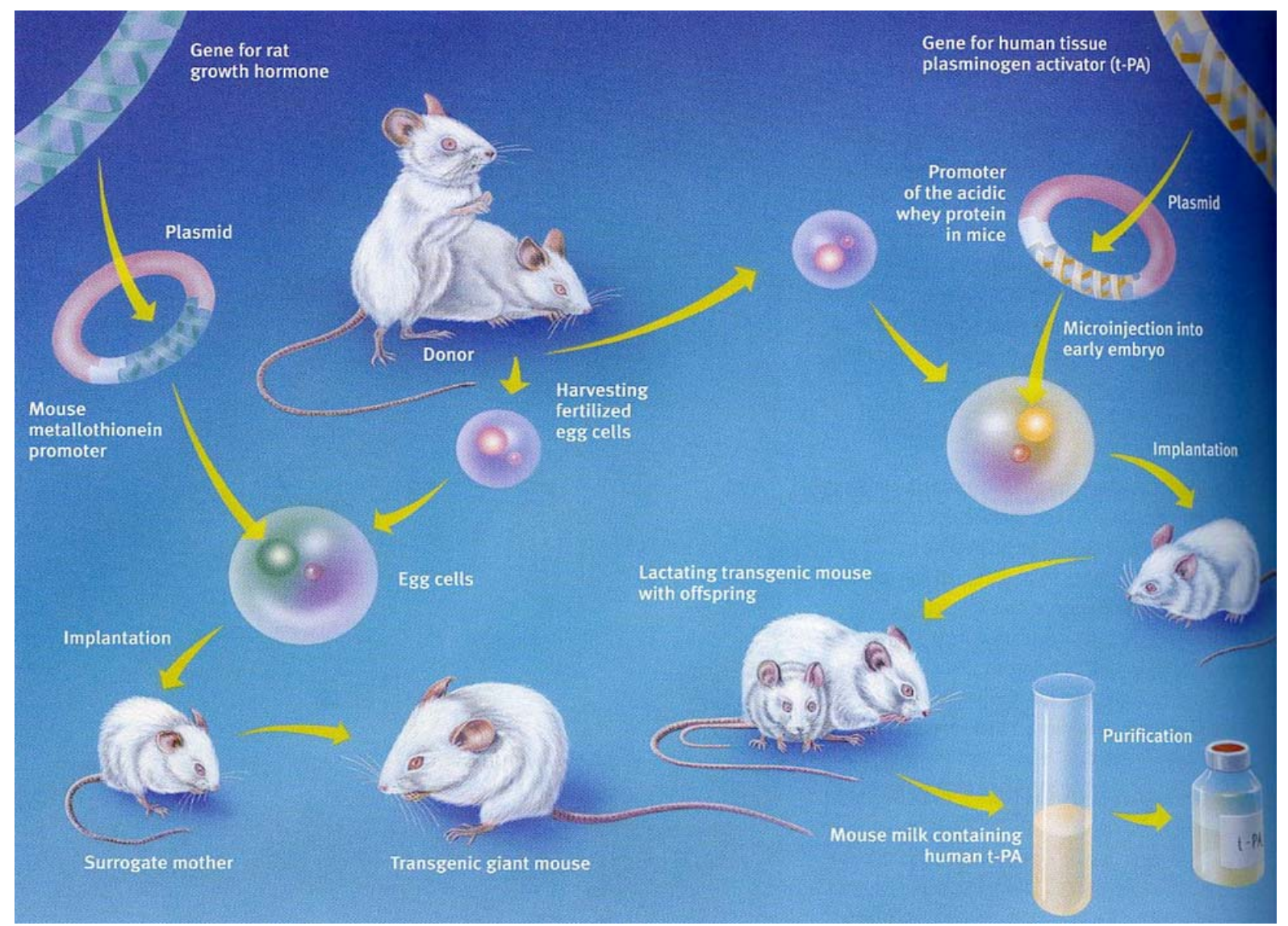

Fig. 2 Selecting the gene of interest in biotechnology.

harm the environment plus non target organisms.

(4) Bigger hectares of European corn borer suppression. Generally the population of European corn borer should decrease substantially, if farmers grow GM corn for a number of successive years [5].

(5) The process of selecting the desired gene with its characteristic traits and inserting that gene into a species to be improved has become the dogma of science today (Fig. 2).

(6) Better quality food like rice with vitamin A, higher nutritional foods like carrots with more antioxidants, food with medicinal benefits, such as edible vaccines for example bananas with bacterial or rotavirus antigens.

(7) Farmers, who have struggled for years with insects pests and have spent a lot of money controlling these pests, can now go to sleep at night with a peace of mind knowing that their crops are safe, while expecting quality yields. This has led to the global hectarage of biotech crops to increase 100-fold from 1.7 million ha in 1996 to 179.7 million ha in 2015 by up to 17-18 million farmers. This impressive adoption rate speaks for itself in terms of significant benefits delivered to both small and large famers as well as consumers [6]. The countries of the world that have adopted biotech crops are shown in Fig. 1.

The USA has made significant progress ranging from new approvals, new commercialized biotech crops and first time approval of a GM animal food product. For GM animals, after 20 years of review, in a landmark decision in November 2015, the FDA approved the first GM animal for commercial food production and human consumption. A faster growing GM salmon is expected to enter the food chain in the US before 2018; Atlantic salmon normally takes three years to harvest in fish farms, compared with only 18 months, or half the time for GM salmon. The GM AquAdvantage salmon was developed by AquaBounty 
Technologies, which was acquired by the US Company Intrexon in 2015. FDA approved a new GM chicken, whose eggs will be used to treat a rare but fatal human disease called lysosomal acid lipase deficiency.

\section{The Challenge Posed on Food Production by World Population}

The world population is standing at 7.3 billion [6]. The feeding of 9.7 billion people in 2050 and approximately 11 billion by 2100 is one of the most daunting challenges facing mankind during the remaining years of this century [7]. Globally 870 million people are currently chronically hungry and 2 billion are malnourished [7]. It is now evident that conventional crop technology alone will not feed over 9 billion in 2050 and neither biotechnology a panacea. The world needs a balanced approaching to this challenge, a safe sustainable approach using the best of the conventional crop technology and the best of biotechnology (GM and non-GM traits) to achieve sustainable intensification of crop productivity on the 1.5 billion ha of cropland globally [8].

The rate, at which countries of the world are adopting to the cultivars of GM crops, is so quick that it poses a threat to the long term sustainability of GM crops. Widespread planting of GM crops places selection pressure on the pest populations, which could result in development of resistance to GM crops (virulence) and control failure [9-12]. While it is understandably clear that the world population is on the rise and hence the need to produce more food that will match with demand of the people, we need to also realize that field resistance (including control failure) to a GM crop has been clearly documented in three situations: fall armyworm Spodoptera frugiperda to Cry1F-expressing corn in Puerto Rico, African stem borer (Busseola fusca (Fuller); Lepidoptera: Noctuidae) to Cry1Ab-expressing corn in South Africa, and Pectinophora gossypiella in the Gujarat State of India, etc. [9]. The resistance to Bt toxins by Diabrotica virgifera virgifera (Western corn root worm) is well documented and known throughout the USA. Factors associated with these cases of field resistance have been blamed on the failure to use high-dose GM cultivars and lack of sufficient refuge. These observations support the theory that implementation of the "high-dose/refuge" (HDR) insect resistant management (IRM) strategy has been successful in substantially delaying field resistance to GM crops [10, 13].

The term used in the previous sentence "delaying field resistance" implies that these $O$. nubilalis and any other potential pest to GM crops have the ability to survive on GM, and definitely if they can survive, this represents a potential resistance likely to evolve (their right to survive) and to be seen in the fields and challenge HDR strategy. The coming on the market of pyramided corn, which can produce two or more $\mathrm{Bt}$ proteins with various modes of action on $O$. nubilalis and other pests species of corn, may farther delay the evolution of resistant traits and thus provide an excellent option for managing corn pest resistant to $\mathrm{Bt}$ corn. In Vietnam, GM corn with a Cry 2Ab2 is less sensitive against Ostrinia furnacalis, and they have developed corn seeds with a combination of Cry 1A.105 and Cry 2AB2 proteins. In Philippines, GM corn with Cry 1A.105 is less toxic to Ostrinia furnaculis, while GM corn with Cry 2Ab2 is still more toxic. These resistances pose a big problem to the sustainability of Bt Cry proteins [14].

\section{The Management of Biotechnology}

The transgenic GM corn management lies heavily on two strategies: (1) HDR, where the GM crops need to produce $\mathrm{Bt}$ toxin at high concentration to sufficiently kill most if not all heterozygous individuals of pests; (2) refuges - the availability of non Bt plants, crops, or even weeds that would provide a pool of susceptible individuals. The HDR is expected to work best, when high dose of toxin is expressed in plant tissue, resistance alleles are rare (these are recessive alleles). The refuge strategy is expected to work, if resistance to Bt toxin is conferred 
by rare recessive alleles individuals and if most of these extremely rare resistant adults emerging from $\mathrm{Bt}$ crops (all resistant survivors from the GM plants) will mate with susceptible individual from refuge plants to produce heterozygous offspring that cannot survive on GM plants [15]. The theory predicts that such conditions will greatly delay the evolution of resistance to GM crops. That is a theory, it is more probable that the resistant survivors from the GM plants will mate amongst themselves and produce a colony of genetically modified resistant survivors that will not respond to $\mathrm{Bt}$ toxins. The challenge will continue not only how to monitor the evolution of these resistant species of $O$. nubilalis for example, but much more on how to suppress them.

If Charles Darwin was alive today, the insect world would delight and astound him with its impressive verification of his theories of the survival of the fittest. Under the severe stress of intensive chemical spraying and now through $\mathrm{Bt}$ toxins, the weaker members of insect population are being eliminated-killed, while those that are fit continue the process of evolution through insecticide resistance. Evolution of resistance by pests, however, would cut short the efficacy of Bt crops and the associated benefits outlined in the introduction.

Three quarters of the peasant farmers (with little resources) around the world will not be able to implement refuge strategy, although they might be able to access high dose GM crops. In addition to their poor economy of subsistence farming, there is a lingering uncertainty of weather. Will there be enough rain or not? The farmer is justifiably reluctant to invest in technologies, which will make him incur losses at the end of the year, because there may be no crop at all if there were no rains. There are a few traditionally good methods that can be implemented along with GM crops.

\section{Alternatives to Biotechnology}

Alternatives to pest control of using $\mathrm{Bt}$ toxins should be exploited, such as the exploitation of semiochemicals which are natural signals that affect changes in the behavior of organisms. The semiochemicals can be classified into two groups:

(1) Allelochemicals, which are classified as allomones, kairomone or synomones. Allomones are often found in nature as part of a chemical defence, such as toxic insect secretions. Predators also use allomones to lure prey. Kairomones are compounds that advantage the receiver, such as predators and bugs by guiding them to prey or potential host insects.

(2) Pheromones: a chemical substance produced and released into the environment by an animal, especially a mammal or an insect, affecting the behavior or physiology of others of its species. Pheromones can be divided into different categories: aggregation pheromones are compounds that increase the concentration of insects at the pheromone source; alarm pheromone are those compounds that stimulate insects' escape or defense behavior; sex pheromones are those compounds that help individuals of the opposite sex to find each other; trail pheromones are common among social insects and are compounds used by workers to mark the way to a food source or new home, etc..

From as far as 1950 up to date, more than 3,000 semiochemicals connected to the chemical communication of insects have been identified. Current research on semiochemicals involves continued molecular mapping, synthesis and studies of biosynthesis [16]. The practical goal of such research on semiochemicals is to develop means and methods of ameliorating the impact and controlling of insects in crops. Pheromones were used when monitoring European corn borer moth in field research, and there is need to expand this use beyond monitoring. The challenges here are minimal, i.e., the extraction and selection of these semiochemicals from insects and applying them in the fields where they can prevent pests from attacking crops.

The second option to Bt toxins is by biological 
control agents, which range from pathogens of pests to antagonistic organisms, such as predators and parasitoids. As an example, Tembo and Pavuk [17] found spinosaid more effective in controlling $O$. nubilalis than other control measures. Spinosad is derived from the metabolites of natural occurring bacteria Saccharopolyspora spinosa originally got from the Carribean. It provides effective control of pests belonging to the following groups: moths and butterflies, flies, mosquitoes, ants, thrips, some beetles and grass hopper family. Spinosad is associated with excitation of the insect nervous system. It uniquely alters the function of nicotinic and gamma-aminobutyric acid (GABA) gated ion channels in a manner consistent with the observed neuronal excitation [18]. Spinosad has shown no cross resistance with existing chemistries and can be rotated with all other classes of existing and experimental products, making it an ideal for resistance management in pest control.

\section{Push and Pull Strategy}

The other pest management strategy that can be exploited particularly by peasant farmers around the global other than $\mathrm{Bt}$ toxins is the pull and push strategy for European corn borer or maize stem borers (major constraint to increased maize production in Africa), such as Chilo partellus, Eldana saccharina and Busseola fusca. The pull and push strategy involves planting crops that attract pests (pull), while driving them away (push) from the main crop (Fig. 3). Some plants have been identified to be effective in the management of stem borers for maize, for example, the Napier grass (Pennisetum purpureum) and Sudan grass (Sorgum vulgare var. sudanense) can be used as pull by attracting the pests, while Molasses grass (Melinis minutiflora) and Desmodium (D. uncinatum, $D$. intortum) plants push or repel the stem borers away.

Yield losses are minimized as stem borers are pulled (attracted) away from the maize (corn) by Napier grass and repelled (pushed away) by Desmodium grass. Local seed companies could be involved in producing seeds for such grasses and community-based seed production among farmers who adopt the push-pull technologies. The grasses in

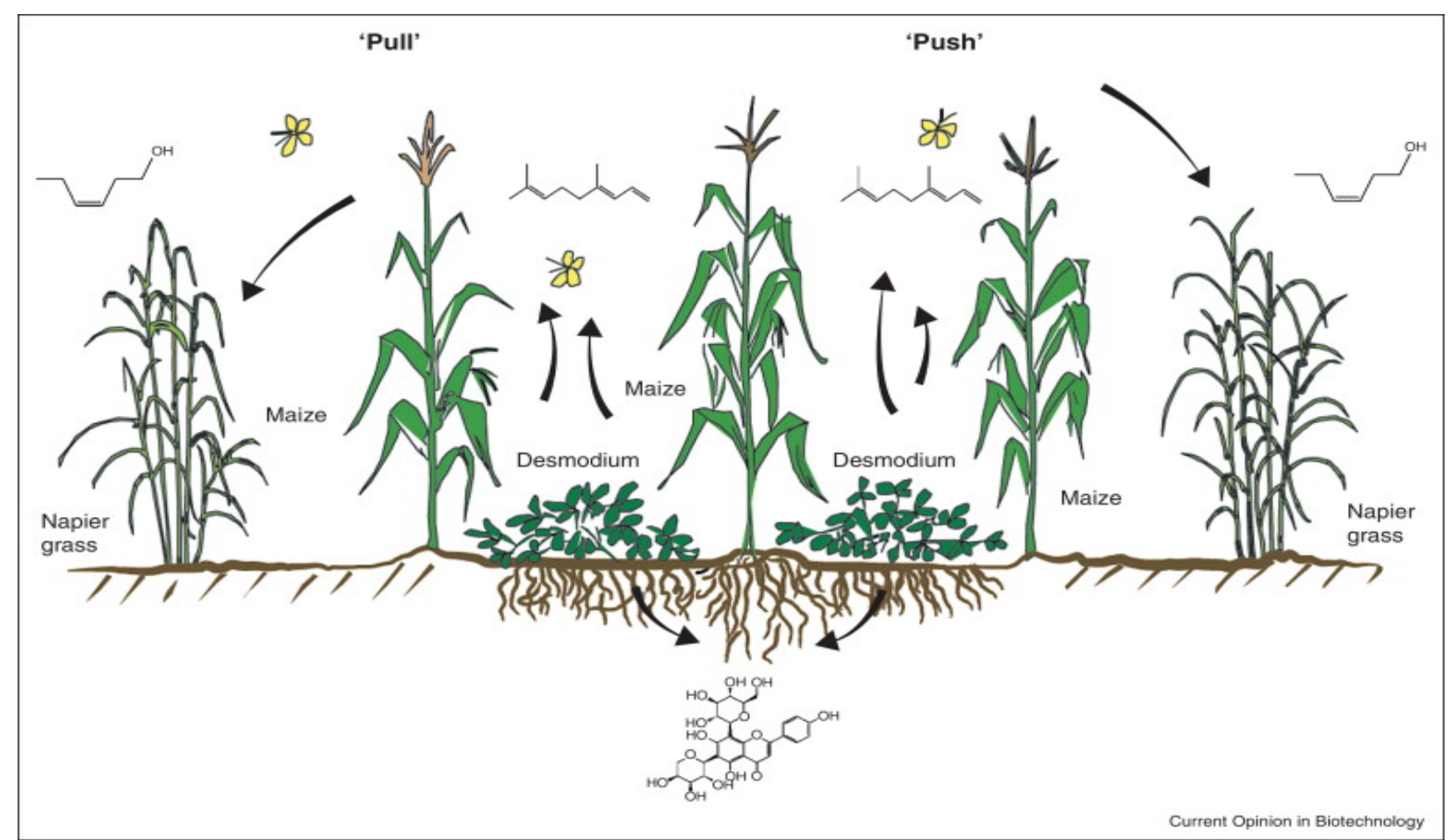

Fig. 3 The pull-push strategy for controlling cereal stem borers [19]. 
the border and around the maize field are planted to attract adult moths, and the moth become attracted to the chemicals emitted by the grasses. Instead of the moths coming to land on the maize to lay their eggs, they land on this grass with tastier chemicals and lay their eggs there. This and other integrated pest management strategies could be exploited extensively while maintaining organically grown food [20]. The whole purpose of using such primitive-looking techniques is to maximize the control of the pest (stem borers), the efficacy and sustainability, while minimizing the negative environmental effects on non-target organisms wrought by conventional spraying and the maintenance of the safety of the food being produced. The challenges would be to maintain the seeds for grasses, such as Napier and Desmodium. Technology, such as biotechnology, should be subjected to fair public scrutiny, because technologies by themselves are neither good nor bad, however how they are used makes them good or bad.

\section{The Challenges of the Biotechnology}

Many countries have taken the route of a precautionary approach. In most studies conducted so far on the safety of GM crops, record no fragments of transgenic DNA were detected in any animal derived products [21]. The level of safety of GMO (foods) to consumers appears to raise some worries, despite what has been made public that the safety of GM foods is equivalent to that of traditional foods. However, recently there are cases of concern on the presence of transgenic DNA in both "organic” and "conventional” cattle milk that have been reported [22]. In 2014 a study was conducted on long term toxicity of a Roundup herbicide and a Roundup-tolerant GM maize (NK603) fed on rats [23]. The findings showed the differences in multiple organ functional parameters seen from the consumption of NK603 GM maize for 90 days, escalated over two years into severe organ damage. The consumption of NK603 GM maize with or without Roundup application or Roundup alone gave similar pathologies in rats fed over two year period. This is not very clear whether the organ damage to rats fed on maize NK603 was due to GM maize or Roundup [23]. But the scientific opinion on this was that the NK603 GM maize is safe [24].

Amyotrophic lateral sclerosis (ALS) is a relentless progressive neurodegenerative disorder that selectively damages motor neuron. The pathological features of ALS are the progressive death of motor neurons in the motor cortex of the cerebrum, in the brain. The ALS associated proteins, like, Cu/Zn superoxide dismutase I (SODI), transactivation response (TAR) or DNA binding protein or fused in sarcoma (FUS) or translocated in liposarcoma (TLS) are protein inclusions. Li et al. [25] examined the expression and distribution of FUS/TLS protein in the different anatomical regions, segments and neural cells of adult spinal cord at different stages of the SODI wild type mice and G93A transgenic mice using the fluorescent immunohistochemistry. Results revealed that, in the SODI wild type mice, the FUS/TLS expression almost was not detected. However, in the SODI G93A transgenic mice, the FUS/TLS expression in the white matter was significantly more than that in the gray matter and other neural cells. The FUS/TLS expression was positively correlated with neuronal death. The results suggested that the expressive increase and mislocalization of FUS/TLS in the astrocyte cell might cause the motor neuron degenerative death in the SODI G93A transgenic mice. Changes in the expression of FUS/TLS in spinal cords of SOD1 G93A transgenic mice correlated motor-neuron degeneration, which was a matter of concern. What will be the situation like to consume crops that will have high dose of Cry protein toxins the one more effective against resistant insects to GM crops if the normal toxins have such effects? We must proceed with caution to avoid causing unintended harm to human health and the environment as a result of the enthusiasm for this powerful technology. So far, there 
is no consensus on GM food safety. In a comprehensive review of animal feeding studies of GM crops, the review found an equilibrium in the number of research groups, suggesting on the basis of studies that a number of varieties of GM products (mainly corn and soybean) are as safe as the respective conventional non GM crops and those raising serious concerns. The second point is that there are no epidemiological studies investigating the potential effects of GM foods consumption on human health. It is therefore scientifically impossible to trace, let alone study patterns of consumptions and their impacts on human health [26].

Allergenic reactions are important health issues with the prevalence of immunoglobulin $\mathrm{E}$ (IgbE) antibody-mediated food allergies among adults being approximately $2 \%$ and nearly $5 \%$ in children $[27,28]$. Food allergies share several common properties due to their proteins or glycoproteins with acidic isoelectric points and are usually in the molecular mass range of 10,000 to 80,000 [27]. Most characterize food allergens are stable to digestion and processing and many of the major allergens are generally proteins that are present in large amounts in allergenic foods. There has been indication of increased allergic reactions with foods that have been genetically modified, e.g. nuts, wheat, legumes, cow milk and especially peanuts and soybeans produce approximately $90 \%$ of all food allergies in the USA [29, 30].

GMOs are not a panacea to all ills; it is one of many technologies available in the Gene Toolkit. There are a lot of people globally who are uncomfortable consuming GM crops. One would think everyone in the USA does not mind GM foods, but on the contrary, majority mind and given an option where all GM foods could be labeled; majority of people would possibly not buy GM crops or their derivatives. Much of Europe, especially Britain people, have not accepted the consumption of GM crops, despite of a good number of researches done on the safety of these transgenic crops. Also most commercial farmers in
Africa are reluctant to adopt GM crops for fear of losing the market in Europe where their customers do not need transgenic crops.

In 2001 and 2002, there was severe drought in Southern Africa that people had run out of corn and some had started eating leaves, twigs and even poisonous berries and nuts to cope up with the worst food crisis in a decade. Still their government refused to accept donations of GM corn which the United Nations and aid agencies said could help ease the starvation and suffering of about 2.5 million Zambians who were affected particularly in Southern province. The United States, United Nations and humanitarian aid groups insisted that the US-donated corn was safe and identical to grain eaten daily by people in the United States, Canada and other countries. But Zambian officials were scared that the gene-altered corn posed health risks to their citizens. "We would rather starve than get something toxic" said by Zambian president Levy Mwanawasa, who had declared a food emergency in the nation three months earlier [31]. Lesotho, Malawi and Swaziland agreed to accept the US donations, after the World Health Organization and several US agencies certified the US corn as safe. Zimbabwe and Mozambique accepted the grain on the condition that it would be milled before distribution to prevent people from planting it. Was this the fear of the unknown or the fear had substance?

\section{Conclusions}

We are at a stage in human development, where we need a balanced approach to this world challenge of hunger and malnourishment, a safe sustainable approach using the best of the conventional crop technology and the best of biotechnology to achieve sustainable intensification of crop productivity on the 1.5 billion ha of cropland globally. Biotechnology has the potential to provide benefits to people and societies, but it can also have negative effects or unintended consequences. This is true of all forms of 
technology, not just biotechnology. However, biotechnology can offer different types of benefits and pose different types of dilemmas than other forms of technology.

It is important that biotechnology innovations (like other technological innovations) be carefully tested and analyzed before they are released for general use. Clinical trials and government regulations help ensure that biotechnology products placed on the market are safe and effective. However, sometimes new information becomes available that makes companies and government agencies reconsider the safety or utility of an innovation. We see this happening when a medication is occasionally withdrawn from the market. Also crops genetically engineered to make their own insecticide reduce the need for chemical spraying, but also raise concerns about plants escaping into the wild or interbreeding with local populations (potentially causing unintended ecological consequences), or worse still unforeseeable problems that could arise on human population by virtue of consuming GM foods. The possible transfer and accumulation of novel DNA and/or proteins in food for human consumption derived from animals receiving GM feed is at present the object of scientific dispute and research concentration. It is astounding that 20 years after the onset of GM crops there is still a debate on the safety of the technology.

\section{Acknowledgments}

Very grateful to the authors Christine Woodcock and John Pickett who have given me permission to use their figures. Also acknowledge the support of Clive James for 20th Anniversary (1996-2015) of the Global Commercialization of Biotech Crops and Biotech Crop Highlights in 2015, ISAAA Brief No. 51, ISAAA, Ithaca, NY.

\section{References}

[1] Saladin, K. S. 2015. Anatomy and Physiology: The Unity of Form and Function, 7th ed.. New York: McGraw Hill Publishing Company, 115-6.
[2] Canadian Biotechnology Action Network (CBAN). 2015. "A Report: Where in the World Are Genetically Modified Crops and Foods?” Collaborative Campaigning for Food Sovereignty and Environmental Justice. Accessed March 19, 2015. http://www.cban.ca/.

[3] National Agricultural Statistics Service (NASS). 2009. "The Magnitude and Impacts of the Biotech and Organic Seed Price Premium by Charles Benbrook.” The Organic Center. Accessed December 2009. https://www.organic-center.org/.

[4] James, C. 2015. 20th Anniversary (1996-2015) of the Global Commercialization of Biotech Crops and Biotech Crop Highlights in 2015. ISAAA Brief No. 51, ISAAA, Ithaca, NY.

[5] Rice, M. E., and Pilcher, C. D. 1998. "Potential Benefits and Limitations of Transgenic Bt Corn for Management of the European Corn Borer (Lepidoptera: Crambidae).” American Entomologist 44 (2): 75-8.

[6] International Service for the Acquisition of AgriBiotech Applications (ISAAA). 2015. "Global Status of Commercialized Biotech/Genetically Modified Crops 2015.” Accessed April 13, 2016. http://global farmernetwork.org/2016/04/20-years-of-success-global-st atus-of-commercialized-biotechgm-crops-2015-isaaa/.

[7] United Nations (UN). 2015. "World Population Prospects.” The 2015 Revision, Population Division of the Department of Economic and Social Affairs of the United Nations. Accessed July 2015. https://esa.un.org/unpd/wpp/.

[8] International Service for the Acquisition of AgriBiotech Applications (ISAAA). 2016. “An Update on Global Status of Commercialized Biotech/Genetically Modified Crops.” Accessed September 21, 2016. https://www.isaaa.org.

[9] Blair, D. S., and Hellmich, R. L. 2012. "The European Corn Borer and Bt Corn in the United States.” Department of Entomology, University of Nebraska-Lincoln. Accessed October 5, 2012. http://digitalcommons.unl.edu/entomologyfacpub/446/.

[10] Gould, F. 1998. "Sustainability of Transgenic Insecticidal Cultivars: Integrating Pest Genetics and Ecology.” Annu. Rev. Entomol. 43: 701-26.

[11] Ostlie, K. R., Hutchison, W. D., and Hellmich, R. L., eds. 1997. Bt Corn and European Corn Borer: Long Term Success through Resistance Management. St. Paul: University of Minnesota.

[12] Tabashnik, B. E., Gassmann, A. J., Crowder, D. W., and Carriere, Y. 2008. "Insect Resistance to Bt Crops Evidence versus Theory.” Nat. Biotechnol. 26 (2): 199-202.

[13] Huang, F., Andow, D. A., and Buschman, L. L., 2011. "Success of the High Dose/Refuge Resistance Management Strategy after 15 Years of Bt Crop Use in 
North America.” Entomol. Exp. Appl. 140 (1): 1-16.

[14] Lang, Z. H., Zhang, J., and Huang, D. F. 2016. "Status, Acceptance and Challenges of Genetically Modified Crops-Chinese Perspective.” Presented at 25th International Congress of Entomology (ICE), September 25-30, 2016, Orlando, Florida, USA.

[15] Alstand, D. N., and Andow, D. A. 1995. "Managing the Evolution of Insect Resistance to Transgenic Plants." Science 268 (5219): 1894-6.

[16] Pickett, J. A., Aradottir, G. I., Birkett, M. A., Bruce, T. J. A., Chamberlain, K., Khan, Z. R., Midega, C. A. O., Smart, L. E., and Woodcock, C. M. 2012. "Aspects of Insect Chemical Ecology: Exploitation of Reception and Detection as Tools for Deception of Pests and Beneficial Insects.” Physiol. Entomol. 37 (1): 2-9.

[17] Tembo, R. D., and Pavuk, D. M. 2011. "The Impact of Beauveria bassiana, Bacillus thuringiensis (Bt) Spray, Trichogramma pretiosum and Spinosad on the Lepidoptera: Crambidae, European Corn Borer (Ostrinia nubilalis)." Journal of Agricultural Science and Technology A 1: 678-92.

[18] Salgado, V. L. 1998. "Studies on the Mode of Action of Spinosad: Insect Symptoms and Physiological Correlates.” Pestic. Biochem. Physiol. 60 (2): 91-102.

[19] Woodcock, C., and Pickett, J. 2008. Management of Cereal Stem Borers in Africa. Harpenden, Hertfordshire, United Kingdom: Rothamsted Research.

[20] Khan, Z. R., and Pickett, J. A. 2004. "The Push-Pull Strategy for Stem Borer Management: A Case Study in Exploiting Biodiversity and Chemical Ecology.” In Ecological Engineering for Pest Management: Advances in Habitat Manipulations for Arthropods, edited by Gurr, G., Waratten, S. D., and Altieri, M. A. Collingwood, Australia: CSIRO Publishing \& Wallingford and UK: CABI Publishing, 155-64.

[21] International Life Sciences Institute (ILSI). 2008. "Nutritional and Safety Assessments of Foods and Feeds Nutritionally Improved through Biotechnology." Comprehensive Review in Food Science and Safety 3 (2): 50-99.

[22] Agodi, A., Barchitta, M., Grillo, A., and Salvatore, S.
2006. "Detection of Genetically Modified DNA Sequences in Milk from the Italian Market.” Int. J. Hyg. Environ. Health 209 (1): 81-8.

[23] Seralini, G. E., Clair, E., Mesnage, R., Gress, S., Defarge, N., Malatesta, M., Hennequin, D., and De Vendômois, J. S. 2014. "Republished Study: Long-Term Toxicity of a Roundup Herbicide and a Roundup-Tolerant Genetically Modified Maize.” Environmental Science Europe 26: 14.

[24] The European Food Safety Authority (EFSA). 2015. Annual Report on Scientific Cooperation on European Food Safety.

[25] Li, J., Lu, Y., Liang, H. T., Tang, C. Y., Zhu, L., Zhang, J., and $\mathrm{Xu}, \mathrm{R}$. S. 2016. "Changes in the Expression of FUS/TLS in Spinal Cords of SOD1 G93A Transgenic Mice and Correlation with Motor-Neuron Degeneration.” Int. J. Biol. Sci. 12 (10): 1181-90.

[26] Hilbeck, A., Binimelis, R., Defarge, N., Steinbrecher, R., Székács, A., Wickson, F., Antoniou, M., Bereano, P. L., Clark, E. A., Hansen, M., Novotny, E., Heinemann, J., Meyer, H., Shiva, V., and Wynne, B. 2015. "No Scientific Consensus on GMO Safety.” Environ. Sci. Eur. 27: 4.

[27] Lehrer, S. B. 1999. "Safety Assessment of Foods Derived from Genetically Modified Plants: Allergenicity.” Presented at Beijing Conference, China, October 1999.

[28] Lehrer, S. B. 2000. "Potential Health Risks of Genetically Modified Organisms: How Can Allergens Be Assessed and Minimized?” In Agricultural Biotechnology and the Poor, edited by Persley, G. J., and Lantin, M. M. Washington. DC: Consultative Group on International Agricultural Research.

[29] Ladics, G. S., Holsapple, M. P., Astwood, J. D., Kimber, I., Knippels, L. M., Helm, R. M., and Dong, W. 2003. "Approaches to the Assessment of Allergenic Potential of Food from Genetically Modified Crops.” Toxicol. Sci. 73 (1): 8-16.

[30] Bakshi, A. 2003. "Potential Adverse Health Effects of Genetically Modified Crops.” J. Toxicol. Environ. Health. B-Crit. Rev.6 (3): 211-25.

[31] United Nations. 2004. "World Chronicle.” Accessed May 27, 2004. http://www.un.org/webcast/worldchron/ trans943.pdf. 